\title{
Methane production and digestion of different physical forms of rapeseed as fat supplements in dairy cows
}

\author{
M. Brask, ${ }^{*}$ P. Lund, ${ }^{* 1}$ M. R. Weisbjerg, ${ }^{*}$ A. L. F. Hellwing, ${ }^{*}$ M. Poulsen, ${ }^{*}$ M. K. Larsen, $†$ and T. Hvelplund ${ }^{*}$ \\ *Department of Animal Science, and \\ †Department of Food Science, Aarhus University, AU Foulum, PO Box 50, DK 8830 Tjele, Denmark
}

\begin{abstract}
The purpose of this experiment was to study the effect of the physical form of rapeseed fat on methane $\left(\mathrm{CH}_{4}\right)$ mitigation properties, feed digestion, and rumen fermentation. Four lactating ruminal-, duodenal-, and ileal-cannulated Danish Holstein dairy cows (143 d in milk, milk yield of $34.3 \mathrm{~kg}$ ) were submitted to a $4 \times$ 4 Latin square design with 4 rations: 1 control with rapeseed meal (low-fat, CON) and 3 fat-supplemented rations with either rapeseed cake (RSC), whole cracked rapeseed (WCR), or rapeseed oil (RSO). Dietary fat concentrations were 3.5 in $\mathrm{CON}, 5.5$ in RSC, 6.2 in WCR, and $6.5 \%$ in RSO. The amount of fat-free rapeseed was kept constant for all rations. The forage consisted of corn silage and grass silage and the forage to concentrate ratio was 50:50 on a dry matter basis. Diurnal samples of duodenal and ileal digesta and feces were compiled. The methane production was measured for $4 \mathrm{~d}$ in open-circuit respiration chambers. Additional fat reduced the $\mathrm{CH}_{4}$ production per kilogram of dry matter intake and as a proportion of the gross energy intake by 11 and $14 \%$, respectively. Neither the total tract nor the rumen digestibility of organic matter $(\mathrm{OM})$ or neutral detergent fiber were significantly affected by the treatment. Relating the $\mathrm{CH}_{4}$ production to the total-tract digested $\mathrm{OM}$ showed a tendency to decrease $\mathrm{CH}_{4}$ per kilogram of digested OM for fat-supplemented rations versus $\mathrm{CON}$. The acetate to propionate ratio was not affected for RSC and WCR but was increased for RSO compared with CON. The rumen ammonia concentration was not affected by the ration. The milk and energy-corrected milk yields were unaffected by the fat supplementation. In conclusion, rapeseed is an appropriate fat source to reduce the enteric $\mathrm{CH}_{4}$ production without affecting neutral detergent fiber digestion or milk production. The physical form of fat did not influence the $\mathrm{CH}_{4}$-reducing effect of rapeseed fat.
\end{abstract}

Received December 7, 2011.

Accepted December 28, 2012.

${ }^{1}$ Corresponding author: Peter.Lund@agrsci.dk
However, differences in the volatile fatty acid pattern indicate that different mechanisms may be involved.

Key words: canola, fiber digestion, cattle

\section{INTRODUCTION}

Globally, agriculture accounts for $47 \%$ of total anthropogenic methane $\left(\mathrm{CH}_{4}\right)$ emissions, with enteric fermentation contributing $32 \%$ of the total non- $\mathrm{CO}_{2}$ emissions from agriculture in 2005 (Smith et al., 2007). The $\mathrm{CH}_{4}$ production per animal varies depending on the feed composition, feed quality, and production level from 2 to $12 \%$ of the gross energy (GE) intake (Johnson and Johnson, 1995) under extreme circumstances, but values between 3 and 7\% (Martin et al., 2008) are more realistic in intensive dairy production.

Numerous studies have discussed nutritional possibilities to reduce the enteric $\mathrm{CH}_{4}$ production (Boadi et al., 2004; Beauchemin et al., 2008), and fat supplementation is among the most promising tools to depress $\mathrm{CH}_{4}$ production from ruminants (Martin et al., 2008). Furthermore, fat is fed to dairy cows to increase the energy density of the ration or to alter the product quality (Beauchemin et al., 2007). Several oils and oil seeds have been tested for their potential to reduce the $\mathrm{CH}_{4}$ production, and effects of chain length and saturation have been reported. The degree of saturation is important, as the negative effect on bacterial growth increases with the degree of unsaturation, inhibiting both fibrolytic bacteria and methanogens (Giger-Reverdin et al., 2003). With reduced fiber digestibility and a shift in fermentation pattern, less hydrogen arises and, thus, less $\mathrm{CH}_{4}$ (Boadi et al., 2004). Additionally, fat often replaces carbohydrates in the ration, thereby directly reducing rumen fermentation. Reduced fiber digestibility is associated with reduced DMI and milk production; therefore it has to be considered whether the overall reduction of $\mathrm{CH}_{4}$ production from the animal due to the addition of fat is accompanied by a reduction per kilogram of product or per kilogram of feed digested.

Feeding whole seeds or cake, a by-product from the plant oil production, as well as pure oil, are tools to increase the dietary fat concentration, but the difference 
in physical form might influence the effect of fat in the rumen. Czerkawski et al. (1966) showed that the effect of $\mathrm{FA}$ on $\mathrm{CH}_{4}$ production was stronger when the same amount was infused to the rumen once daily, compared with continuous infusion. Similarly, Machmüller et al. (2000) concluded that this could be of importance to achieve momentarily high fat concentrations in the rumen rather than a constant presence at a lower level. Oil in seeds is stored intracellularly, and the fat release depends on the digestion and breakdown of the cell wall, which leads to a slower release compared with feeding oil directly (Steele et al., 1971). This indicates that pure oil may increase the rumen FA concentration faster and reduce the $\mathrm{CH}_{4}$ production more effectively compared with seeds or cake (Martin et al., 2008).

Oilseed rape (Brassica napus) is widely grown in many countries. The by-products, rapeseed meal and cake, remaining after oil extraction are common feed components in dairy cow rations. Rapeseed meal has a low crude fat concentration (about 4\%) compared with rapeseed cake (10-20\%) and whole seeds (approximately $50 \%$ ). The aim of the current experiment was to study the effect of rapeseed fat and the physical form in which it was fed on enteric $\mathrm{CH}_{4}$ production, rumen fermentation, and digestion.

\section{MATERIALS AND METHODS}

\section{Animals and Rations}

The experiment complied with the guidelines of the Danish Ministry of Justice with respect to animal experimentation and care of animals under study. Four lactating Danish Holstein dairy cows (1 primiparous and 3 multiparous) were assigned to 1 of 4 rations over 4 periods according to a balanced Latin square design; each period consisted of 4 wk. One cow was omitted from the last period due to disease.

The cows were 143 DIM ( $\mathrm{SD}=74 \mathrm{~d})$, had a milk yield of $34.3 \mathrm{~kg}(\mathrm{SD}=8.6 \mathrm{~kg})$, and a $\mathrm{BW}$ of $592 \mathrm{~kg}(\mathrm{SD}=$ $81 \mathrm{~kg}$ ) at the beginning of the experiment. All animals were fitted with a ruminal cannula (\#1C, Bar Diamond Inc., Parma, ID), a duodenal cannula (open T-piece placed $60 \mathrm{~cm}$ caudal to pylorus), and an ileal cannula (open T-piece placed $20 \mathrm{~cm}$ cranial to the cecum). The cows were housed in a tie stall with rubber mats and sawdust as bedding and had free access to water. They were milked and fed twice daily at 0500 and $1700 \mathrm{~h}$. Total mixed rations were prepared once a day and fed to the cows on an ad libitum basis after milking. The feed intake was recorded on a daily basis. The animals were weighed at the start of the experiment as well as just before and after the respiration chamber measurements (the last week of each period).
The rations were a control ration $(\mathbf{C O N})$ and 3 highfat rations with fat supplemented as either rapeseed cake (RSC), whole cracked rapeseed (WCR), or rapeseed oil (RSO), respectively. The amount of fat-free rapeseed was equal for all rations, as the basic rapeseed meal content in the CON was reduced according to the fat-free rapeseed which was supplemented with either cake or seed in the treatment rations. Rapeseed cake, whole rapeseed, and rapeseed oil were obtained from Danraps (DLG Food Oil, Dronninglund, Denmark). The rapeseed used in this study was double-00 rape, equivalent to what is known as canola in North America.

The chemical composition of ingredients is shown in Table 1. All rations were fed as TMR with a forage to concentrate ratio of 50:50 (Table 2). The forage consisted of $54 \%$ corn silage and $46 \%$ prewilted perennial ryegrass silage (on DM basis). The corn silage was stored in a bunker silo and the grass silage in bales.

\section{Measurements}

The milk production and composition were measured once a week during morning and evening milkings. Weekly samples of the feed ingredients were stored $\left(-20^{\circ} \mathrm{C}\right)$ and pooled during the whole experiment. Samples of TMR and refusals were taken daily in connection with the afternoon feeding, stored $\left(-20^{\circ} \mathrm{C}\right)$, and pooled for each period from d 15 to 20 .

Chromic oxide was used as a flow marker, and $10 \mathrm{~g}$ was administrated to the rumen via the ruminal cannula during each of the 2 daily feedings, except when the cows were in the respiration chambers.

Samples of duodenal chyme $(600 \mathrm{~mL})$, ileal chyme $(300 \mathrm{~mL})$, and feces $(350 \mathrm{~mL})$ were taken from d 15 to 19 at 1000, 1800 (d 15), 0200, 1200, 2000 (d 16), 0400, 1400, 2200 (d 17), 0600, 1600, 2400 (d 18), and 0800 h (d 19; 12 samples, representing every second hour of the day). Samples from the duodenum and ileum were taken in tube-formed plastic bags which were mounted to the cannulas with plastic knees. Duodenal, ileal, and fecal samples were added to the frozen pooled sample from previous samples at each sampling time. At the end of the period, representative subsamples from thawed material were taken and freeze-dried for chemical analysis. At the 12 sampling times, rumen liquid was sampled from the ventral ruminal sac with a collection tube (\#RT, Bar Diamond Inc.). The rumen liquid $\mathrm{pH}$ was measured immediately, and two 8-mL samples were taken and frozen $\left(-20^{\circ} \mathrm{C}\right)$ immediately for VFA and ammonia $\left(\mathrm{NH}_{3}\right)$ analysis at each sampling time.

\section{Chemical Analysis}

Ash was determined by combustion at $525^{\circ} \mathrm{C}$ for 6 h. Nitrogen was determined by the Dumas principle 
Table 1. Chemical composition ( $\mathrm{g} / \mathrm{kg}$ of DM unless otherwise noted) of feedstuffs

\begin{tabular}{|c|c|c|c|c|c|c|c|c|}
\hline Item & Barley & $\begin{array}{l}\text { Beet } \\
\text { pulp }\end{array}$ & $\begin{array}{c}\mathrm{RS}^{1} \\
\text { meal }\end{array}$ & $\begin{array}{l}\mathrm{RS} \\
\text { cake }\end{array}$ & $\begin{array}{c}\text { Whole } \\
\text { RS }\end{array}$ & RS oil & $\begin{array}{l}\text { Grass } \\
\text { silage }\end{array}$ & $\begin{array}{l}\text { Corn } \\
\text { silage }\end{array}$ \\
\hline $\mathrm{DM}, \mathrm{g} / \mathrm{kg}$ of fresh matter & 878 & 903 & 904 & 968 & 940 & & 424 & 295 \\
\hline $\mathrm{OM}$ & 980 & 958 & 922 & 937 & 960 & & 896 & 966 \\
\hline Crude fat & 30.0 & 4.8 & 54.7 & 173 & 479 & 1,000 & 30.8 & 30.0 \\
\hline NDF & 161 & 408 & 260 & 201 & 150 & & 420 & 392 \\
\hline $\mathrm{INDF}^{2}$ & 36.4 & 28.2 & 96.7 & 90.0 & 53.6 & & 56.8 & 92.1 \\
\hline \multicolumn{9}{|l|}{ Fatty acids, $\mathrm{g} / \mathrm{kg}$ of DM } \\
\hline C16:0 & 6.30 & 1.99 & 3.53 & 8.44 & 19.0 & 43.7 & 2.93 & 3.73 \\
\hline C18:0 & 4.20 & 0.06 & 0.74 & 2.46 & 6.35 & 15.5 & 0.30 & 3.60 \\
\hline C18:1 & 2.98 & 0.82 & 20.2 & 80.3 & 218 & 537 & 0.85 & 4.28 \\
\hline $\mathrm{C} 18: 2$ & 10.8 & 1.19 & 11.7 & 33.4 & 80.4 & 191 & 2.72 & 9.10 \\
\hline $\mathrm{C} 18: 3$ & 0.96 & 0.23 & 3.46 & 13.7 & 38.2 & 91.4 & 10.4 & 2.39 \\
\hline
\end{tabular}

${ }^{1} \mathrm{RS}=$ rapeseed.

${ }^{2} \mathrm{INDF}=$ indigestible NDF.

${ }^{3} \mathrm{OMD}=$ in vitro $\mathrm{OM}$ digestibility.

${ }^{4}$ Sum of fatty acids includes, beside those shown, C16:1, C20:0, C20:1, C20:2, and C22:0.

(Hansen, 1989), and CP was calculated as $\mathrm{N} \times 6.25$. Crude fat was analyzed as Soxhlet extraction with petroleum ether (Soxtec 2050, Foss Analytical, Hillerød, Denmark) after hydrolyzing with $\mathrm{HCl}$ (Stoldt, 1952). The NDF content was analyzed by neutral detergent extraction according to Mertens (2002) with a Fibertec M6 System (Foss Analytical) using heat-stable amylase and corrected for ash. The indigestible NDF in freezedried ground $(1.5 \mathrm{~mm})$ feed samples was determined as residual NDF after $288 \mathrm{~h}(12 \mathrm{~d})$ of Dacron bag incubation in the rumen of 3 heifers fed a standard ration (Åkerlind et al., 2011). The GE was determined by adiabatic bomb calorimeter (Parr 6300 Oxygen Bomb Calorimeter, Parr Instrument Company, Moline, IL).

The concentrations of VFA were analyzed according to the method described by Canibe et al. (2007) using a Hewlett Packard gas chromatograph (model 6890; Agilent Technologies Inc., Wilmington, DE) equipped with a flame ionization detector and a 30-m SGE BP1 column (Scientific Instrument Services, NJ). Fatty acids in feed were analyzed by GC after an acidic Bligh and Dyer extraction with hydrochloric acid-water-chloroform and methanol, and subsequent methylation as described by Jensen (2008). For determination of $\mathrm{NH}_{3}$,

Table 2. Ration ingredients and chemical composition ( $\mathrm{g} / \mathrm{kg}$ of DM unless otherwise noted)

\begin{tabular}{lcccc}
\hline & \multicolumn{3}{c}{ Ration $^{1}$} \\
\cline { 2 - 5 } Item & CON & RSC & WCR & RSO \\
\hline Barley & 143 & 137 & 137 & 138 \\
Beet pulp dried & 143 & 137 & 137 & 138 \\
Rapeseed meal, 4\% fat & 190 & 62 & 149 & 184 \\
Rapeseed cake, 17\% fat & 0 & 156 & 0 & 0 \\
Rapeseed, cracked & 0 & 0 & 69 & 0 \\
Rapeseed oil & 0 & 0 & 0 & 33 \\
Corn silage & 238 & 232 & 232 & 232 \\
Grass silage & 286 & 275 & 275 & 275 \\
DM, g/kg of fresh matter & 479 & 500 & 492 & 494 \\
OM & 934 & 937 & 939 & 939 \\
CP & 169 & 171 & 168 & 171 \\
Crude fat & 35 & 55 & 62 & 65 \\
Fatty acids & 26 & 43 & 50 & 53 \\
NDF & 332 & 328 & 326 & 322 \\
Gross energy, MJ/kg of DM & 18.4 & 18.9 & 19.1 & 19.1 \\
NE , MJ/kg of DM & 7.6 & 7.8 & 8.0 & 8.1 \\
\hline
\end{tabular}

${ }^{1} \mathrm{CON}=$ control, $\mathrm{RSC}=$ rapeseed cake, $\mathrm{WCR}=$ whole cracked rapeseed, $\mathrm{RSO}=$ rapeseed oil.

${ }^{2}$ Calculated values based on analysis of ingredients. 
the rumen fluid was made alkaline with $\mathrm{KOH}$, and $\mathrm{NH}_{3}$ was determined by titration after distillation.

Chromic oxide was determined by colorimetry after oxidation to chromate (Schürch et al., 1950). The OM digestibility was determined in vitro for grass and corn silage as described by Tilley and Terry (1963). Milk concentrations of fat, protein, and lactose were analyzed by a Milkoscan Msc4000 infrared analyzer (Foss Analytical).

\section{Methane Measurements}

During the fourth week of each period, the $\mathrm{CH}_{4}$ production was measured for $2 \times 48 \mathrm{~h}$ in four $17-\mathrm{m}^{3}$ opencircuit respiration chambers (Hellwing et al., 2012). The animals were housed individually. The chambers were covered with transparent polycarbonate and placed in a square so that the cows faced each other. The chambers were located in the barn where the cows were usually housed to minimize changes in the environment and the daily routines during the $\mathrm{CH}_{4}$ measurements were identical to the period outside the chambers. The mean ambient temperature in the chambers was $21.1^{\circ} \mathrm{C}$, ranging from 15.6 to $29.5^{\circ} \mathrm{C}$.

The cows changed chambers diagonally after the first $48 \mathrm{~h}$ to balance out any differences in background levels of $\mathrm{CH}_{4}$ and $\mathrm{CO}_{2}$. Cow and chamber were confounded over periods and, therefore, every ration was tested in every chamber.

The chambers were opened twice daily, at 0500 and $1700 \mathrm{~h}$, for about $20 \mathrm{~min}$ during milking and subsequent feeding. Methane was measured as the accumulated amount (L) over $24 \mathrm{~h}$ and is reported under standard conditions $\left(0^{\circ} \mathrm{C}, 101.325 \mathrm{kPa}\right)$. The measurements during the openings of the chambers for milking and feeding were deleted (about $60 \mathrm{~min} / \mathrm{d}$ ). The $\mathrm{CH}_{4}$ production during this period was assumed to correspond to the mean of the rest of the day.

The air flow was measured by a HFM-200 flow meter with a laminar flow element from Teledyne Hastings Instruments (Hampton, VA). The background (inlet air), as well as the chamber outlet air concentration of $\mathrm{CH}_{4}$, was measured every $121 / 2$ min with an infrared analyzer. All instruments were from Columbus Instruments (Columbus, OH). The air flow was adjusted individually for every animal depending on the $\mathrm{BW}$ and milk yield to obtain a $\mathrm{CO}_{2}$ concentration in the chamber below, but close to 9,000 ppm. The instruments were calibrated every second day with zero gas (nitrogen) and a span gas with nitrogen and 20.55\% $\mathrm{O}_{2}, 5,000 \mathrm{ppm} \mathrm{CO}_{2}$, and $800 \mathrm{ppm} \mathrm{CH}_{4}$ (Yara Praxair AS, Oslo, Norway). The temperature, humidity, and $\mathrm{CO}_{2}$ concentration of the chamber air were monitored with independent sensors (Veng System A/S, Roslev, Denmark) for alarm purposes.

\section{Calculations and Statistical Analysis}

The net energy content in feeds was calculated in Scandinavian Feed Units (SFU; Weisbjerg and Hvelplund, 1993) and presented in megajoules of $\mathrm{NE}_{\mathrm{L}}$ by using a fixed conversion factor of $7.89 \mathrm{MJ}$ of $\mathrm{NE}_{\mathrm{L}} / \mathrm{SFU}$, as described by Hvelplund et al. (2007). Content of SFU is calculated based on content of ash, CP, crude fiber, crude fat, and in vitro OM digestibility.

The apparent rumen digestibility was calculated as the feed intake minus the duodenal flow divided by feed intake. Apparent small intestine digestibility was calculated as the duodenal flow minus ileal flow divided by duodenal flow and, accordingly, apparent large intestine digestibility as ileal flow minus fecal flow divided by ileal flow.. Apparent total-tract digestibility was calculated as the feed intake minus fecal flow divided by feed intake.

Average ECM yield for each cow per period was calculated according to Sjaunja et al. (1991) as follows: $\mathrm{ECM}=$ milk yield $\times(383 \times$ fat $\%+242 \times$ protein $\%$ $+783.2) / 3,140$. For samples with repeated measures (VFA, $\mathrm{NH}_{3}$, and $\mathrm{pH}$ ), an average for each cow-period was calculated before the statistical analysis.

The data was evaluated with the MIXED procedure (SAS 9.2 version, SAS Institute Inc., Cary, NC) with treatment and period as fixed effects and cow as random effect.

The results are reported as LSM and SEM for each treatment. The SEM was different for RSO because one cow receiving RSO was omitted. Therefore, the RSO SEM is reported and a factor for the SEM of the other treatments is noted under each table. Apart from the mean treatment effect, the significance of orthogonal contrasts were calculated for CON versus fat supplement, RSC and WCR versus RSO, and RSC versus WCR. $P$-values $<0.05$ were regarded as significant and $P<0.1$ as a tendency.

\section{RESULTS}

\section{Milk Production}

Average milk production and ECM were not significantly affected by the treatment (Table 3). The milk fat content was numerically lower in fat supplemented rations compared with CON. Milk protein content was numerically higher on RSC and WCR than on RSO $(P$ $=0.71$ ). Daily milk fat production in $\mathrm{g} / \mathrm{d}$ was 1,187 , 1,170, 1,164, and 968 for CON, RSC, WCR, and RSO, 
Table 3. Milk production and composition

\begin{tabular}{|c|c|c|c|c|c|c|c|c|c|}
\hline \multirow[b]{2}{*}{ Item } & \multicolumn{4}{|c|}{ Rations $^{1}$} & \multirow[b]{2}{*}{$\mathrm{SEM}^{2}$} & \multirow[b]{2}{*}{$P$-value ${ }^{3}$} & \multicolumn{3}{|c|}{ Contrast $(P \text {-value })^{4}$} \\
\hline & $\mathrm{CON}$ & $\mathrm{RSC}$ & WCR & $\mathrm{RSO}$ & & & $\begin{array}{c}\text { CON } \\
\text { vs. Fat }\end{array}$ & $\begin{array}{c}\text { RSC and } \\
\text { WCR vs. RSO }\end{array}$ & $\begin{array}{c}\text { RSC } \\
\text { vs. WCR }\end{array}$ \\
\hline Milk, kg/d & 27.4 & 31.2 & 28.1 & 26.3 & 4.61 & 0.23 & 0.52 & 0.16 & 0.18 \\
\hline Milk fat, $\mathrm{g} / \mathrm{kg}$ & 40.4 & 39.1 & 41.2 & 37.9 & 4.39 & 0.90 & 0.78 & 0.62 & 0.64 \\
\hline Milk protein, $\mathrm{g} / \mathrm{kg}$ & 33.5 & 33.1 & 32.9 & 32.4 & 1.13 & 0.71 & 0.35 & 0.51 & 0.83 \\
\hline Milk lactose, $\mathrm{g} / \mathrm{kg}$ & 46.4 & 46.8 & 46.1 & 46.4 & 1.28 & 0.26 & 0.80 & 0.99 & 0.07 \\
\hline $\mathrm{ECM}, \mathrm{kg} / \mathrm{d}$ & 27.2 & 30.2 & 25.1 & 28.4 & 4.37 & 0.12 & 0.61 & 0.04 & 0.29 \\
\hline
\end{tabular}

${ }^{1} \mathrm{CON}=$ control, $\mathrm{RSC}=$ rapeseed cake, $\mathrm{WCR}=$ whole cracked rapeseed, $\mathrm{RSO}=$ rapeseed oil.

${ }^{2} \mathrm{SEM}$ for RSO; the SEM for the other treatments is the presented SEM $\times 0.93$.

${ }^{3}$ Fixed effect of treatment.

${ }^{4}$ Linear orthogonal contrasts of treatment.

respectively. Daily milk protein production was 915, 1,030, 928, and $849 \mathrm{~g} / \mathrm{d}$ for CON, RSC, WCR, and RSO. The yield of milk solids per day was not affected by the ration.

\section{Feed Intake}

The DMI was not affected by the treatments. The intake was numerically greater for cows consuming CON and RSC than WCR and RSO. The higher GE content in the 3 fat-supplemented rations compensated for the numerically lower DMI, and the GE intake was similar between CON and fat-supplemented rations. As planned, fat intake increased in the fat-supplemented rations, and NDF and CP intakes were not affected, as shown in Table 4. Adding rapeseed to the ration increased the intake of total FA from $471 \mathrm{~g} / \mathrm{d}$ in CON to 804,835 , and $892 \mathrm{~g} / \mathrm{d}$ for RSC, WCR, and RSO, respectively. Compared with $\mathrm{CON}$, adding fat almost doubled the absolute intake of $\mathrm{C} 18: 0(P=0.001)$ and tripled the intake of $\mathrm{C} 18: 1(P<0.003)$.

\section{Digestibility}

Duodenal, ileal, and fecal flows were unaffected by the treatment, except for an increased fat flow in the fat-supplemented rations (data not shown). Neither total-tract nor ruminal apparent digestibility was affected by the treatment for any measured nutrient (Table 4). The flow of crude fat to the duodenum was higher than intake by an average of $210 \mathrm{~g} / \mathrm{d}$, or $22.7 \%$; no difference was observed between rations in ruminal fat digestibility $(P=0.46)$. The NDF digestibility in the hind gut was close to zero for all rations except RSC.

\section{VFA, Ammonia, and Rumen $\mathrm{pH}$}

Fat supplementation did not affect VFA concentrations in the rumen $(P=0.24)$. Bound-fat supplements (rapeseed cake, whole rapeseed) resulted in higher propionic acid proportion $(P=0.005)$, and tended to reduce the acetic acid proportion $(P=0.07)$ compared with free supplement (oil). Consequently, the acetate to propionate ratio was 2.95 for RSO and 2.76, 2.73, and 2.74 for CON, RSC, and WCR, respectively, resulting in a significant difference $(P=0.01)$ between the 2 bound-fat supplements and RSO (Table 5).

The ammonia concentration in the rumen fluid was not influenced by the ration $(P=0.19)$, but a tendency for a higher concentration in RSC than in WCR $(P=$ 0.06 ) was noted. The rumen $\mathrm{pH}$ was within the normal physiological range: an average of 6.29 for the 16 observations ranging from 5.60 to 6.91 .

\section{Methane Production}

Adding rapeseed fat to the ration reduced the enteric $\mathrm{CH}_{4}$ production significantly in liters per day and also related to the feed intake and ECM yield (Table 6). The average reduction ( $\mathrm{L}$ of $\mathrm{CH}_{4}$ per $\mathrm{kg}$ of DMI per percent fat added) was 4.6, 4.8, and $3.8 \%$ for RSC, WCR, and RSO, respectively. A tendency was observed for a reduction in $\mathrm{CH}_{4}$ per kilogram of $\mathrm{OM}$ digested in the whole digestive tract $(P=0.08)$ when fat was added, but the ration had no effect on $\mathrm{CH}_{4}$ per kilogram of totally digested carbohydrate or NDF and per kilogram of ruminally digested OM and NDF.

\section{DISCUSSION}

\section{Intake and Milk Production}

The rations were calculated to have identical crude fat content. However, the fat content in the rapeseed cake was not as high as planned, which resulted in a lower fat content in RSC.

We hypothesized that fat supplementation at the present levels would only reduce $\mathrm{CH}_{4}$ production with- 
Table 4. Intake and apparent digestibility of nutrients

\begin{tabular}{|c|c|c|c|c|c|c|c|c|c|}
\hline Item & \multicolumn{4}{|c|}{ Ration $^{1}$} & $\mathrm{SEM}^{2}$ & $P$-value ${ }^{3}$ & \multicolumn{3}{|c|}{ Contrast $(P \text {-value })^{4}$} \\
\hline Intake, $\mathrm{kg} / \mathrm{d}$ & 18.3 & 18.9 & 17.9 & 15.8 & 2.07 & 0.54 & 0.62 & 0.22 & 0.58 \\
\hline \multicolumn{10}{|l|}{$\mathrm{OM}$} \\
\hline Intake, $\mathrm{kg} / \mathrm{d}$ & 17.1 & 17.7 & 16.8 & 14.9 & 1.96 & 0.56 & 0.64 & 0.23 & 0.61 \\
\hline \multicolumn{10}{|l|}{ NDF } \\
\hline Intake, $\mathrm{kg} / \mathrm{d}$ & 6.10 & 6.20 & 5.83 & 5.18 & 0.74 & 0.59 & 0.54 & 0.27 & 0.60 \\
\hline Duodenal flow, $\mathrm{kg} / \mathrm{d}$ & 2.35 & 2.16 & 2.17 & 1.93 & 0.32 & 0.43 & 0.18 & 0.31 & 0.96 \\
\hline Rumen digestibility, \% & 61.7 & 65.5 & 62.7 & 63.9 & 2.57 & 0.22 & 0.14 & 0.93 & 0.13 \\
\hline Hindgut digestibility, $\%$ & 1.55 & 9.64 & 1.28 & 1.83 & 6.39 & 0.61 & 0.66 & 0.63 & 0.29 \\
\hline Total-tract digestibility, $\%$ & 61.7 & 63.3 & 60.4 & 61.1 & 2.37 & 0.60 & 0.98 & 0.72 & 0.23 \\
\hline Total-tract digestibility, $\%$ & 65.4 & 67.8 & 65.1 & 58.0 & 4.29 & 0.25 & 0.59 & 0.07 & 0.50 \\
\hline FA intake, $\mathrm{g} / \mathrm{d}$ & 471 & 804 & 835 & 892 & 89.1 & 0.009 & 0.002 & 0.88 & 0.30 \\
\hline \multicolumn{10}{|l|}{$\mathrm{CP}$} \\
\hline Intake, $\mathrm{kg} / \mathrm{d}$ & 3.09 & 3.23 & 3.00 & 2.70 & 0.35 & 0.53 & 0.68 & 0.23 & 0.48 \\
\hline Duodenal flow, kg/d & 3.66 & 3.46 & 3.61 & 3.26 & 0.45 & 0.78 & 0.51 & 0.50 & 0.69 \\
\hline Ruminal digestibility, $\%$ & -19.0 & -6.88 & -21.3 & -16.3 & 5.16 & 0.21 & 0.44 & 0.73 & 0.06 \\
\hline Total-tract digestibility, $\%$ & 65.1 & 66.9 & 64.5 & 64.5 & 1.63 & 0.52 & 0.85 & 0.52 & 0.22 \\
\hline
\end{tabular}

${ }^{1} \mathrm{CON}=$ control, $\mathrm{RSC}=$ rapeseed cake, $\mathrm{WCR}=$ whole cracked rapeseed, $\mathrm{RSO}=$ rapeseed oil.

${ }^{2} \mathrm{SEM}$ for RSO; the SEM for the other treatments is the presented SEM $\times 0.86$.

${ }^{3}$ Fixed effect of treatment.

${ }^{4}$ Linear orthogonal contrasts of treatment.

out affecting feed energy intake and milk yield. Negative effects of fat supplementation on DMI have been reported in some (Harvatine and Allen, 2006; Martin et al., 2008) but not all previous studies (Johnson et al., 2002; Moate et al., 2011). The effect of fat on DMI and GE intake depends on the level of supplementa- tion. When cows are fed a low level of supplementation, DMI remains unaffected and GE intake increases, due to a higher energy density. When a moderate amount of fat is supplemented, DMI is reduced but GE intake is unchanged, whereas a further increase of the fat concentration in the ration can reduce the DMI to an

Table 5. Rumen VFA, ammonia, and $\mathrm{pH}$ (mean of 12 diurnal samples)

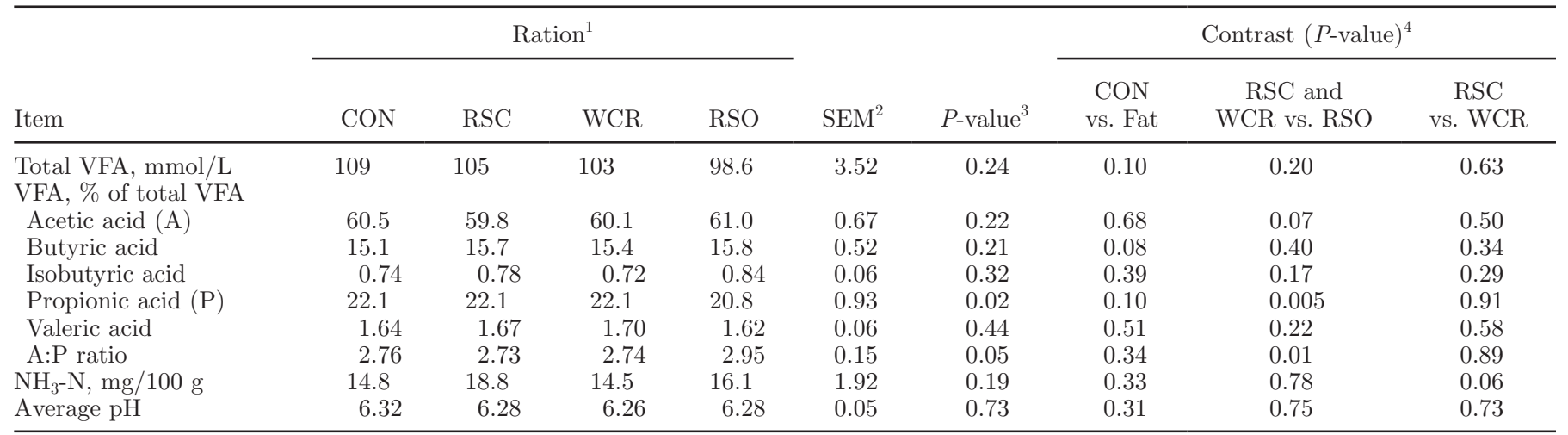

${ }^{1} \mathrm{CON}=$ control, $\mathrm{RSC}=$ rapeseed cake, $\mathrm{WCR}=$ whole cracked rapeseed, $\mathrm{RSO}=$ rapeseed oil

${ }^{2} \mathrm{SEM}$ for RSO; the SEM for the other treatments is the presented SEM $\times 0.91$.

${ }^{3}$ Fixed effect of treatment.

${ }^{4}$ Linear orthogonal contrasts of treatment. 
Table 6. Methane production

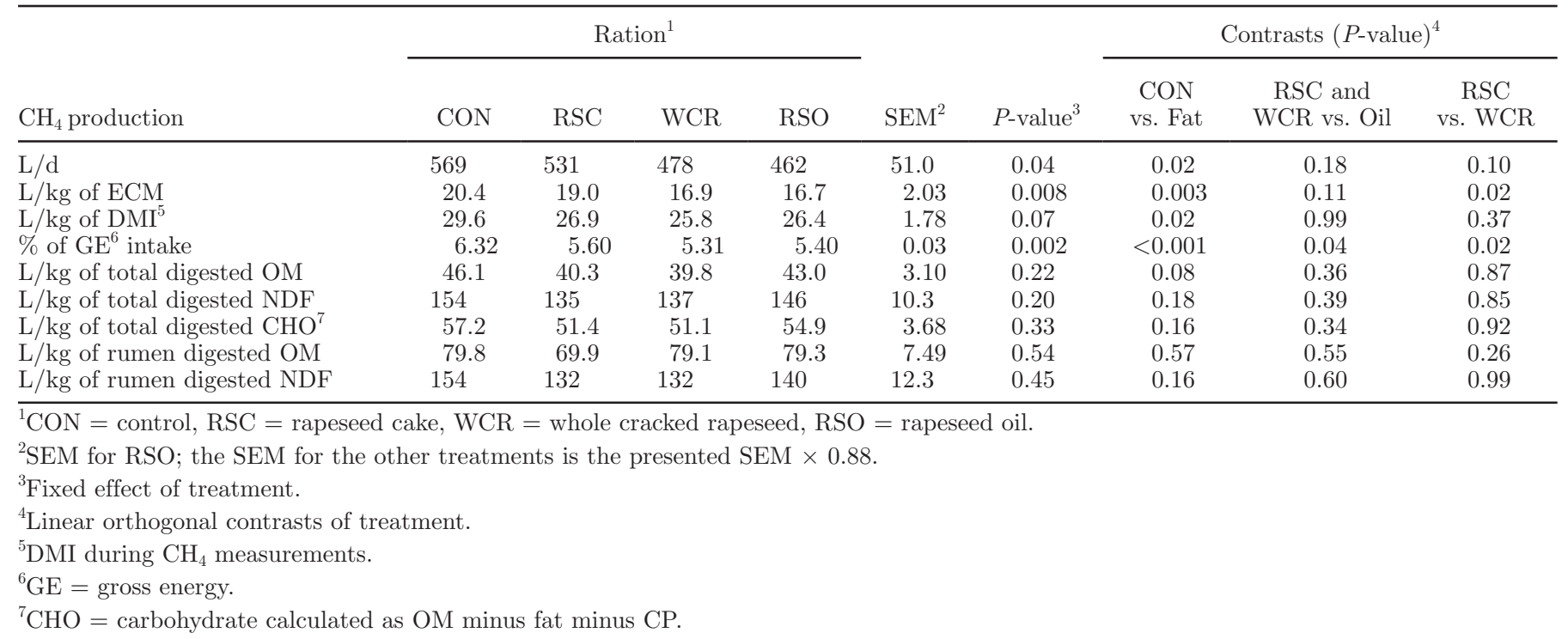

extent where the GE intake is also reduced (Grainger and Beauchemin, 2011). Neither DMI nor GE intake was affected significantly in the present study, indicating that the fat concentration in the rations $(5.5-6.5 \%$ of DM) was within the nutritionally acceptable range. The rapeseed oil supplementation numerically reduced the DMI by $2.2 \mathrm{~kg}$ compared with CON, but the cows responded differently to the addition of oil, which is illustrated by the higher standard deviation between cows for DMI on RSO (5.3 kg) compared with the other rations $(3.1 \mathrm{~kg})$. This was also supported by heterogeneous variance for DMI, as a likelihood ratio test showed. Dry matter intake depression can be expected when the dietary fat concentration exceeds 6 to $7 \%$ (Beauchemin et al., 2007). A fat concentration of $6.5 \%$ in RSO in the present study may therefore be at a borderline where it affects some, but not necessarily all, animals. This was illustrated by the pronounced depressing effect of oil supplementation on DMI for the 2 cows with the highest feed intake level (per $\mathrm{kg}$ of BW) compared with the 2 cows with the lowest feed intake level (values not shown).

\section{NDF Digestibility}

Ruminal NDF digestibility was $63 \%$ on average, which is in accordance with previous studies with similar ration compositions (Lund et al., 2007). Rapeseed fat includes mainly monounsaturated FA and was presented at moderate concentrations in the present study; therefore, it did not affect NDF digestibility. The same effect has been observed with comparable additions of rapeseed (Chelikani et al., 2004; Beauchemin et al., 2009).
Few studies have compared how different physical forms of the same fat affect digestion. Even though effects of the physical form and processing of whole seeds were reported for linseed (Martin et al., 2008), this might not be valid for rapeseed. Pallister and Smithard (1987) found no effect of whole or extruded rapeseed or rapeseed oil on fiber digestion, using a comparable fat content in the control ration and slightly higher levels in the fat-supplemented rations compared with the present experiment. Ferlay et al. (1992) hypothesized that extrusion ruptures cell membranes and increases the availability of fat. However, in an experiment with feeding raw and extruded rapeseed to dairy cows, no effect on digestion was noted (Ferlay et al., 1992). This might be due to the high fat content in rapeseed compared with other oilseeds (Ferlay et al., 1992).

Total-tract NDF digestibility was lower than the ruminal NDF digestibility for all fat-supplemented rations. That problem has been observed earlier in connection with flow markers (Faichney, 1972; Lund et al., 2007) and different types of duodenal cannulas (Stensig and Robinson, 1997). The hindgut digestibility of NDF was higher for RSC compared with the other rations, but still within the physiological range (Huhtanen et al., 2006).

\section{Fat Digestibility}

The fat digestibility in the rumen was negative for all rations. Schmidely et al. (2008) reported, in a metaanalysis, a slightly positive FA balance from feed to duodenum (duodenal flow - intake). However, they found a net disappearance of FA with higher intake (50-120 $\mathrm{g}$ of $\mathrm{FA} / \mathrm{kg}$ of $\mathrm{DMI})$. In the present study, 
RSO only slightly exceeded the $50 \mathrm{~g}$ of $\mathrm{FA} / \mathrm{kg}$ of $\mathrm{DM}$, and the other rations had a lower FA content. Scollan et al. (2001) reported a positive net FA flow to the duodenum with an increase in rumen FA balance by $21.8 \%$ when steers receive rations with $60 \mathrm{~g} / \mathrm{kg}$ of DM fat, which fits well with the present experiment where crude fat increased by $22.7 \%$ from feed to duodenum. As observed earlier (Doreau and Chilliard, 1997), a net FA synthesis takes place in the rumen at low to moderate fat contents.

The digestibility of fat in the small intestine is highly variable; Doreau and Chilliard (1997) reported variations from 55 to $92 \%$ in a literature survey. The digestibility of fat in the small intestine depends on the chain length and degree of unsaturation (Weisbjerg et al., 1992; Doreau and Chilliard, 1997). The present digestibility for fat with mainly $\mathrm{C} 18 \mathrm{FA}$ was between 70 and $75 \%$, which is in agreement with earlier reported values (Schmidely et al., 2008). With increasing fat consumption, the intestinal digestibility decreases because the absorptive capacity is limited, but absorption of FA can be higher than $1 \mathrm{~kg} / \mathrm{d}$ (Doreau and Chilliard, 1997). As the highest FA intake in the present experiment was $892 \mathrm{~g} / \mathrm{d}$, fat absorption was not affected by treatment.

\section{VFA and $\mathrm{NH}_{3}$}

Molar concentration of VFA was in agreement with earlier studies with dairy cows receiving rapeseed fat supplementation (Chelikani et al., 2004; Beauchemin et al., 2009). The higher acetate to propionate ratio for RSO compared with CON is surprising, because fat addition is believed to inhibit NDF but not starch fermentation, and therefore the propionic acid proportion was expected to increase as observed by Harvatine and Allen (2006). According to fermentation stoichiometry, a shift in fermentation pattern toward acetate, as observed for RSO, should result in enhanced $\mathrm{CH}_{4}$ production (Boadi et al., 2004). However, cows fed RSO produced less $\mathrm{CH}_{4}$ than on CON. The higher propionate proportion could be due to reduction in total VFA production because less substrate was fermented in the rumen, or because differences were buffered, as the values shown are averages of day and night time measurements.

The ammonia concentration in the rumen is considered to be the balance between entry sources (degradable feed $\mathrm{N}, \mathrm{N}$ recycling) and outputs (incorporation into microbes, $\mathrm{N}$ absorption, ammonia $\mathrm{N}$ outflow; Doreau and Ferlay, 1995). In agreement with previous studies (Oldick and Firkins, 2000), fat addition itself did not affect the protein digestion in the rumen.

\section{Methane Production}

The $\mathrm{CH}_{4}$ production in absolute numbers $(\mathrm{L} / \mathrm{d})$, as well as in relation to intake, was comparable to previous studies (Beauchemin et al., 2008; Moate et al., 2011). The reduction in $\mathrm{CH}_{4}$ loss expressed as the proportion of GE intake when rapeseed fat was supplemented was less than found by Beauchemin et al. (2009) with dairy cows (18 vs. $14 \%$ in the present study) or Machmüller et al. (2000) with lambs (22\%). This was most likely due to a higher fat concentration (Beauchemin et al., 2009) and a higher forage proportion (Machmüller et al., 2000) compared with rations in the present study. The reduction in $\mathrm{CH}_{4}$ per $\mathrm{kg}$ of DMI compared with CON per percentage fat added was highest for WCR $(4.8 \%)$ followed by 4.6 for RSC and $3.8 \%$ for RSO. The present reductions per $\mathrm{kg}$ of DMI were not as high as the $5.6 \%$ reduction found in a review by Beauchemin et al. (2008), but close to the values presented in the review by Grainger and Beauchemin (2011; between 4.7 and $5.1 \%$ depending on fat level in the ration).

Earlier studies with rapeseed found contradictory results; Martin et al. (2011) added 3\% fat as extruded rapeseed to a dairy cow ration without finding any effect on $\mathrm{CH}_{4}$. Beauchemin and McGinn (2006) found a significant reduction in $\mathrm{CH}_{4}$ loss as proportion of $\mathrm{GE}$ when feeding a ration with $4.6 \%$ rapeseed oil added to heifers, but no effect per $\mathrm{kg}$ of DMI. In studies using dairy cows, Moate et al. (2011) found a significant reduction in $\mathrm{CH}_{4}$ per $\mathrm{kg}$ of DMI when adding $2.6 \%$ fat to the ration as a rapeseed-hominy meal mix, and Beauchemin et al. (2009) found a reduction for 1.7\% fat added as crushed rapeseed compared with the control ration.

Beauchemin and McGinn (2006) observed a feed intake depression and therefore, no effect on $\mathrm{CH}_{4}$ per $\mathrm{kg}$ of DMI was observed when heifers received rapeseed oil. In a later study, Beauchemin et al. (2009) compared the $\mathrm{CH}_{4}$-reducing properties of different oil seeds and emphasized that rapeseed did not depress DMI in contrast to other oil seeds. The present results and those of Moate et al. (2011) confirm that rapeseed fat does not always depress feed intake. The depressed feed intake in heifers found by Beauchemin and McGinn (2006) was probably due to the high fat supplementation level.

We hypothesized that fat from seeds is released more slowly in the rumen, and therefore might affect both $\mathrm{CH}_{4}$ production and digestion differently than oil. Martin et al. (2008) found a stronger effect on $\mathrm{CH}_{4}$ production the higher the fat content in the supplement (i.e., extruded linseed being less effective than whole linseed and whole linseed less effective than linseed oil). Conversely, Beauchemin et al. (2007) compared sunflower 
seeds and sunflower oil and found, in agreement with the present study, no difference in the $\mathrm{CH}_{4}$-depressing properties for different physical forms of the same fat source. The linseed fat in the study by Martin et al. (2008) was supplemented at a higher level, and linseed FA have a higher degree of unsaturation than rapeseed or sunflower. Furthermore, the different physical forms in the study by Martin et al. (2008) were confounded with fat contents, as the oil ration included 1.4 and $1.6 \%$ per $\mathrm{kg}$ of DM more fat than extruded and crude seed rations, respectively.

The fat concentration in rapeseed cake was lower than planned, which resulted in a lower fat content in RSC than in WCR and RSO. A meta-analysis by Beauchemin et al. (2008) showed a linear relationship between the percentage of fat added and the reduction in $\mathrm{CH}_{4}$. A rapeseed cake probably would have been more effective in reducing $\mathrm{CH}_{4}$ if it had had a higher fat concentration.

Fat supplementation depresses $\mathrm{CH}_{4}$ production by lowering the quantity of OM degraded in the rumen, by influencing the microbial activity and ecosystem, and, to a very minor extent, by biohydrogenation of unsaturated FA (Johnson and Johnson, 1995). Although rumen digestibilities and VFA composition were not altered, the numeric reduction in $\mathrm{CH}_{4}$ per $\mathrm{kg}$ of digested carbohydrate indicates that fermentation pathways were affected by fat supplementation in addition to the effect of fat being nonfermentable.

An optimal rumen microbial ecosystem is a prerequisite for efficient milk production, and it is well known that methanogens and fibrolytic bacteria may be hampered by addition of fat. The methanogen population of the rumen was studied in parallel to the present study by Poulsen (2012); despite the fact that fat supplementation reduced the $\mathrm{CH}_{4}$ production, the total abundance of the methanogens in the rumen was unaffected by the ration.

\section{CONCLUSIONS}

Supplementation with rapeseed fat up to 6 to $6.5 \%$ fat of ration of DM reduced GE loss of enteric $\mathrm{CH}_{4}$ by $14 \%$ without compromising the NDF digestibility or milk production. Adding fat by supplementing rapeseed in different forms decreased $\mathrm{CH}_{4}$ production and numerically increased milk and ECM yields in the present study, resulting in less $\mathrm{CH}_{4}$ per $\mathrm{kg}$ of product.

\section{ACKNOWLEDGMENTS}

The work was funded by the Danish Ministry of Food, Agriculture and Fisheries, Mælkeafgiftsfonden (Aarhus, Denmark), and Aarhus University. The authors thank Torkild Jakobsen (Aarhus University, Foulum, Denmark) for skillful assistance during the experiment and Ingolf Nielsen (DLG Food Oil, Dronninglund, Denmark) for providing the rapeseed feeds.

\section{REFERENCES}

Åkerlind, M., M. R. Weisbjerg, T. Eriksson, R. Tøgersen, P. Udén, B. L. Ólafsson, O. M. Harstad, and H. Volden. 2011. Feed analyses and digestion methods. Pages 41-54 in NorFor: The Nordic Feed Evaluation System. H. Volden ed. Wageningen Academic Publishers, Wageningen, the Netherlands.

Beauchemin, K. A., M. Kreuzer, F. O'Mara, and T. A. McAllister. 2008. Nutritional management for enteric methane abatement: A review. Aust. J. Exp. Agric. 48:21-27.

Beauchemin, K. A., and S. M. McGinn. 2006. Methane emissions from beef cattle: Effects of fumaric acid, essential oil, and canola oil. J. Anim. Sci. 84:1489-1496.

Beauchemin, K. A., S. M. McGinn, C. Benchaar, and L. Holtshausen. 2009. Crushed sunflower, flax, or canola seeds in lactating dairy cow diets: Effects on methane production, rumen fermentation, and milk production. J. Dairy Sci. 92:2118-2127.

Beauchemin, K. A., S. M. McGinn, and H. V. Petit. 2007. Methane abatement strategies for cattle: Lipid supplementation of diets. Can. J. Anim. Sci. 87:431-440.

Boadi, D., C. Benchaar, J. Chiquette, and D. Masse. 2004. Mitigation strategies to reduce enteric methane emissions from dairy cows: Update review. Can. J. Anim. Sci. 84:319-335.

Canibe, N., O. Højbjerg, J. H. Badsberg, and B. B. Jensen. 2007. Effect of feeding fermented liquid feed and fermented grain on gastrointestinal ecology and growth performance in piglets. J. Anim. Sci. 85:2959-2971.

Chelikani, P. K., J. A. Bell, and J. J. Kennelly. 2004. Effects of feeding or abomasal infusion of canola oil in Holstein cows 1. Nutrient digestion and milk composition. J. Dairy Res. 71:279-287.

Czerkawski, J. W., K. L. Blaxter, and F. W. Wainman. 1966. Effect of linseed oil and of linseed oil fatty acids incorporated in diet on metabolism of sheep. Br. J. Nutr. 20:485-494.

Doreau, M., and Y. Chilliard. 1997. Digestion and metabolism of dietary fat in farm animals. Br. J. Nutr. 78:S15-S35.

Doreau, M., and A. Ferlay. 1995. Effect of dietary lipids on nitrogen metabolism in the rumen: A review. Livest. Prod. Sci. 43:97-110.

Faichney, G. J. 1972. Assessment of chromic oxide as an indigestible marker for digestion studies in sheep. J. Agric. Sci. 79:493-499.

Ferlay, A., F. Legay, D. Bauchart, C. Poncet, and M. Doreau. 1992. Effect of supply of raw or extruded rapeseed on digestion in dairy cows. J. Anim. Sci. 70:915-923.

Giger-Reverdin, S., P. Morand-Fehr, and G. Tran. 2003. Literature survey on the influence of dietary fat composition on methane production in dairy cattle. Livest. Prod. Sci. 82:71-79.

Grainger, C., and K. A. Beauchemin. 2011. Can enteric methane emissions from ruminants be lowered without lowering their production? Anim. Feed Sci. Technol. 166-167:308-320.

Hansen, B. 1989. Determination of nitrogen as elementary-N, an alternative to Kjeldahl. Acta Agric. Scand. Anim. Sci. 39:113-118.

Harvatine, K. J., and M. S. Allen. 2006. Effects of fatty acid supplements on ruminal and total tract nutrient digestion in lactating dairy cows. J. Dairy Sci. 89:1092-1103.

Hellwing, A. L. F., P. Lund, M. R. Weisbjerg, M. Brask, and T. Hvelplund. 2012. Technical note: Test of a low-cost and animal-friendly system for measuring methane emissions from dairy cows. J. Dairy Sci. 96:6077-6085. http://dx.doi.org/10.3168/jds.2012-5505.

Huhtanen, P., S. Ahvenjärvi, M. R. Weisbjerg, and P. Nørgaard. 2006. Digestion and passage of fibre in ruminants. Pages 87-135 in Ruminant Physiology. K. Sejrsen, T. Hvelplund, and M. O. Nielsen, ed. Wageningen Academic Publishers, Wageningen, the Netherlands.

Hvelplund, T., M. R. Weisbjerg, and P. Lund. 2007. Energy and protein evaluation systems used for dairy cows in Denmark. Proc. Soc. Nutr. Physiol . 16:129-131. 
Jensen, S. K. 2008. Improved Bligh \& Dyer extraction procedure. Lipid Technol. 20:280-281.

Johnson, K. A., and D. E. Johnson. 1995. Methane emissions from cattle. J. Anim. Sci. 73:2483-2492.

Johnson, K. A., R. L. Kincaid, H. H. Westberg, C. T. Gaskins, B. K. Lamb, and J. D. Cronrath. 2002. The effect of oilseeds in diets of lactating cows on milk production and methane emissions. J. Dairy Sci. 85:1509-1515.

Lund, P., M. R. Weisbjerg, T. Hvelplund, and K. E. B. Knudsen. 2007. Determination of digestibility of different forages in dairy cows using indigestible NDF as marker. Acta Agric. Scand. Anim. Sci. $57: 16-29$

Machmüller, A., D. A. Ossowski, and M. Kreuzer. 2000. Comparative evaluation of the effects of coconut oil, oilseeds and crystalline fat on methane release, digestion and energy balance in lambs. Anim. Feed Sci. Technol. 85:41-60.

Martin, C., D. Pomiès, A. Ferlay, Y. Rochette, B. Martin, Y. Chilliard, D. P. Morgavi, and M. Doreau. 2011. Methane output and rumen microbiota in dairy cows in response to long-term supplementation with linseed or rapeseed of grass silage- or pasture-based diets. Proc. N.Z. Soc. Anim. Prod. 71:243-247.

Martin, C., J. Rouel, J. P. Jouany, M. Doreau, and Y. Chilliard. 2008. Methane output and diet digestibility in response to feeding dairy cows crude linseed, extruded linseed, or linseed oil. J. Anim. Sci. $86: 2642-2650$.

Mertens, D. R. 2002. Gravimetric determination of amylase-treated neutral detergent fiber in feeds with refluxing in beakers or crucibles: Collaborative study. J. AOAC Int. 85:1217-1240.

Moate, P. J., S. R. O. Williams, C. Grainger, M. C. Hannah, E. N. Ponnampalam, and R. J. Eckard. 2011. Influence of cold-pressed canola, brewers grains and hominy meal as dietary supplements suitable for reducing enteric methane emissions from lactating dairy cows. Anim. Feed Sci. Technol. 166-167:254-264.

Oldick, B. S., and J. L. Firkins. 2000. Effects of degree of fat saturation on fiber digestion and microbial protein synthesis when diets are fed twelve times daily. J. Anim. Sci. 78:2412-2420.

Pallister, S. M., and R. R. Smithard. 1987. The digestion, by sheep, of diets containing different physical forms of rapeseed. J. Agric. Sci. 109:459-465.

Poulsen, M. 2012. Mitigation of methane emission from Holstein dairy cows: Effects of dietary manipulation on bacterial and methanogen communities. PhD Thesis. Aarhus University, Aarhus, Denmark.
Schmidely, P., F. Glasser, M. Doreau, and D. Sauvant. 2008. Digestion of fatty acids in ruminants: A meta-analysis of flows and variation factors. 1. Total fatty acids. Animal 2:677-690.

Schürch, A. F., L. E. Lloyd, and E. W. Crampton. 1950. The use of chromic oxide as an index for determining the digestibility of a diet. J. Nutr. 41:629-636.

Scollan, N. D., M. S. Dhanoa, N. J. Choi, W. J. Maeng, M. Enser, and J. D. Wood. 2001. Biohydrogenation and digetion of long chain fatty acids in steers fed on different sources of lipid. J. Agric. Sci. $136: 345-355$

Sjaunja, L. O., L. Baevre, L. Junkkarinen, J. Pedersen, and J. Setala. 1991. A Nordic proposal for an energy corrected Milk (ECM) formula. Pages 156-157 in EAAP Publication 50: Performance Recording of Animals - State of the Art 1990. Centre for Agricultural Publishing and Documentation (PUDOC), Wageningen, the Netherlands.

Smith, P., D. Martino, Z. Cai, D. Gwary, H. Janzen, P. Kumar, S. McCarl, S. Ogle, F. O'Mara, C. Rice, B. Scholes, and O. Sirotenko. 2007. Agriculture. Pages 497-540 in Climate Change 2007: Mitigation. Contribution of Working Group III to the Fourth Assessment Report of the Intergovernmental Panel on Climate Change. B. Metz, O. R. Davidson, P. R. Bosch, R. Dave, and L. A. Meyer eds. Cambridge University Press, Cambridge, UK.

Steele, W., R. C. Noble, and J. H. Moore. 1971. Effects of 2 methods of incorporating soybean oil into diet on milk yield and composition in cow. J. Dairy Res. 38:43-48.

Stensig, T., and P. H. Robinson. 1997. Digestion and passage kinetics of forage fiber in dairy cows as affected by fiber-free concentrate in the diet. J. Dairy Sci. 80:1339-1352.

Stoldt, W. 1952. Vorschlag zur Vereinheitlichung der Fettbestimmung in Lebensmitteln. Fette und Seifen 54:206-207.

Tilley, J. M. A., and R. A. Terry. 1963. A two-stage technique for in vitro digestion of forage crops. J. Br. Grassl. Soc. 18:104-111.

Weisbjerg, M. R., and T. Hvelplund. 1993. Estimation of net energy content (FU) in feeds for cattle. Page 39 in National Institute of Animal Science, Foulum, Denmark. Report No. 3/1993.

Weisbjerg, M. R., T. Hvelplund, and C. F. Børsting. 1992. Digestibility of fatty-acids in the gastrointestinal tract of dairy cows fed with tallow or saturated fats rich in stearic acid or palmitic acid. Acta Agric. Scand. Anim. Sci. 42:115-120. 